\title{
PRELIMINARY REPORT OF THE USE ON ADULTS OF A RECOMBINANT YEAST-DERIVED HEPATITIS B VACCINE MANUFACTURED BY INSTITUTO BUTANTAN
}

Angela Aparecida COSTA(1), Marta INENAMI(1), Edmundo JUAREZ(1), Pedro Dorlhiac LLACEN(2) \& Isaias RAW(3)

\section{SUMMARY}

Three $10 \mu \mathrm{g}$ doses of the recombinant hepatitis B vaccine, manufactured by Instituto Butantan by original technology, were administered in an adult population, mean age 30 years old, following the 0,1 and 6 months schedule immunization. The clinical trial was considered satisfactory in terms of immunogenicity (anti-HBs titers between 17.5-2950) IU/ I, seroconversion $95.3 \%$ ) and reactogenicity (no incapacitating side effects).

KEYWORDS: Recombinant hepatitis B vaccine; Clinical trials; Adults.

\section{INTRODUCTION}

Prevention of Hepatitis B virus infection is the only effective way to avoid the spread of this disease which can lead to the development of chronic active hepatitis, cirrhosis or primary hepatocellular carcinoma.

Important international manufacturers developed vaccines formulated with Hepatitits B surface antigen ( $\mathrm{HBsAg}$ ) isolated from plasma of infected individuals or by yeast recombinant DNA technology. These vaccines proved to be safe and effective and millions of doses were already distributed around the world during the immunization programs

The Instituto Butantan, in Brazil, also developed a recombinant yeast-derived Hepatitis B vaccine. The vaccine was submitted to the required quality control tests and the results were satisfactory for the pre-clinical phases. That fact led to start up the next phase: the clinical trials. This report describes the results obtained after immunization of healthy volunteers group with the recombinant Hepatitis B vaccine produced in Instituto Butantan.

\section{MATERIALS, SUBJECTS AND METHODS}

22 healthy volunteers were recruited among staff members of SESA (Secretaria Especial de Saúde de Araraquara). The subjects were negative for hepatitis B infection markers including HBsAg, antibodies to $\mathrm{HBsAg}$ (anti-HBs), and antibodies to hepatitis B core antigen (anti-HBc). The volunteers received three $10 \mu \mathrm{g}$ doses of the Instituto Butantan recombinant DNA yeast-derived hepatitis B vaccine injected intramuscularly in the deltoid region, according to a 0,1 and 6 month vaccination schedule. Local reactions and general clinical signs and symptoms were recorded on symptom checklists. Enzyme immunoassays (Abbot Laboratories) were used to HBsAg, anti-HBs and anti-HBc determinations. The anti-HBs titres were expressed in international units per liter (IU/I). The vaccine has been manufactured by original technology following the requirements of $\mathrm{WHO}^{13}$. The main properties of bulk (Table 1) and final product (Table 2) are summarized with data of consecutive lots produced. All lots analysed showed high immunogenicity in mice potency experiments allowing the manufacturer to consider the human dose as $10 \mu \mathrm{g}$. The lot A was used for this clinical trial. Data presented in tables 1 and 2 were recorded in technical reports from Instituto Butantan».

Protective level of anti-HBs $\geq 10$ IU/l was adopted from recent literature ${ }^{12}$.

\section{RESULTS AND DISCUSSION}

In total 21 volunteers were analysed until the end of the immunization schedule. One participant has got pregnant during the immunization period and she did not receive the last dose.

(1) Servico Especial de Saúde de Araraquara, São Paulo, Brasil.

(2) Fundação Pró-Sangue Hemocentro de São Paulo, São Paulo, SP. Brasil.

(3) Instituto Butantan, São Paulo. SP. Brasil.

Correspondence to: Dr. Isaias Raww. Instituto Butantan. Av. Vital Brasil 1500, 05503-900 São Paulo, SP, Brasil. Fax: (011) 815-1505. 
COSTA. A.A.; INENAMI, M.; JUAREZ, E.; LLACEN, P.D. \& RAW, I. - Preliminary report of the use on adults of a recombinant yeast-derived hepatitis B vaccine manufactured by Instituto Butantan. Rev. Inst. Med. trop. S. Paulo, 39(1): 39-42, 1997.

TABLE 1

Characteristics and control tests of Hepatitis B recombinant vaccine (bulk).

\begin{tabular}{|c|c|c|c|c|c|c|c|c|c|c|c|c|c|c|}
\hline \multirow[b]{2}{*}{ Lot } & \multirow{2}{*}{$\begin{array}{l}\text { Plasmid } \\
\text { retention } \\
\%\end{array}$} & \multirow{2}{*}{$\begin{array}{l}\text { Plasmid } \\
\text { structure } \\
\text { stability }\end{array}$} & \multirow{2}{*}{$\begin{array}{l}\text { Antigen } \\
\text { purity } \\
(\geq 98 \%)\end{array}$} & \multirow{2}{*}{$\begin{array}{l}\text { Immuno- } \\
\text { blotting } \\
\text { analysis }\end{array}$} & \multirow[t]{2}{*}{$\begin{array}{l}\text { Disulfide } \\
\text { bonds }\end{array}$} & \multirow[t]{2}{*}{$\begin{array}{l}\text { Morpho- } \\
\operatorname{logy}\end{array}$} & \multirow{2}{*}{$\begin{array}{c}\text { U.V. } \\
\text { spectrum } \\
\text { analysis }\end{array}$} & \multicolumn{3}{|c|}{$\begin{array}{l}\text { Protein concentration } \\
\mu \mathrm{g} / \mathrm{ml} \text { methods }\end{array}$} & \multirow[t]{2}{*}{ Lipids"* } & \multirow[t]{2}{*}{ Sugars:k泘 } & \multirow[t]{2}{*}{$\begin{array}{l}\text { Tween } \\
20^{* * * * * * *}\end{array}$} & \multirow[t]{2}{*}{ 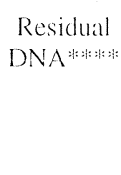 } \\
\hline & & & & & & & & U.V. & Lowry & $\mathrm{BCA}$ & & & & \\
\hline A & 100 & OK & OK & OK & OK & OK & OK & 103.5 & 85.0 & 85.0 & 6.0 & 94 & 25 & $<100$ \\
\hline B & 100 & OK & OK & OK & OK & OK & OK & 75.7 & 52.5 & 52.5 & 9.5 & 19 & $<25$ & $<100$ \\
\hline $\mathrm{C}$ & 100 & OK & OK & OK & OK & $\mathrm{OK}$ & OK & 186.3 & 54.6 & 57.0 & 5.6 & 228 & $<25$ & $<100$ \\
\hline
\end{tabular}

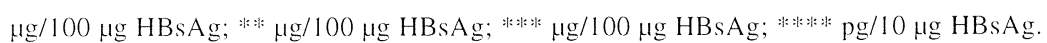

TABLE 2

Characteristics and control tests of Hepatitis B recombinant vaccine (final product)

\begin{tabular}{|c|c|c|c|c|c|c|c|c|c|c|}
\hline \multirow[b]{2}{*}{ Lot } & \multirow[t]{2}{*}{ Sterility } & \multirow{2}{*}{$\begin{array}{l}\mathrm{Al+++} \\
\text { content } \\
\mathrm{mg} / \mathrm{ml}\end{array}$} & \multirow{2}{*}{$\begin{array}{c}\text { Thiomersal } \\
\text { content } \\
\mathrm{mg} / \mathrm{ml}\end{array}$} & \multicolumn{2}{|c|}{ Pirogenicity } & \multirow{2}{*}{$\begin{array}{c}\text { Abnormal } \\
\text { toxicity }\end{array}$} & \multicolumn{2}{|c|}{ Potency } & \multicolumn{2}{|c|}{ Stability at $55^{\circ} \mathrm{C}$} \\
\hline & & & & $\mathrm{LAL} \mathrm{ng/ml}$ & in vivo & & $\begin{array}{l}\text { serocon- } \\
\text { version \% }\end{array}$ & $\mathrm{mIU} / \mathrm{ml}$ & $\begin{array}{l}\text { serocon- } \\
\text { version \% }\end{array}$ & $\mathrm{mlU} / \mathrm{ml}$ \\
\hline A & $\mathrm{OK}$ & 0.51 & 0.04 & OK & $\mathrm{OK}$ & $\mathrm{OK}$ & 100 & 123 & 70 & 95 \\
\hline B & $\mathrm{OK}$ & 0.39 & 0.034 & $\mathrm{OK}$ & $\mathrm{OK}$ & $\mathrm{OK}$ & 100 & 140 & 100 & 78 \\
\hline $\mathrm{C}$ & $\mathrm{OK}$ & 0.46 & 0.035 & $\mathrm{OK}$ & $\mathrm{OK}$ & $\mathrm{OK}$ & 100 & 115 & 70 & 66 \\
\hline $\mathrm{D}$ & n.d. & n.d. & n.d. & n.d. & n.d. & n.d. & 100 & 30 & 80 & 63 \\
\hline $\mathbf{E}$ & n.d. & n.d. & n.d. & n.d. & n.d. & n.d. & 70 & 31 & 50 & 21 \\
\hline $\mathbf{F}$ & n.d. & n.d. & n.d. & n.d. & n.d. & n.d. & 70 & 69 & 60 & 37 \\
\hline
\end{tabular}

D, E, F - available commercial vaccine; n.d. = not done.

Vaccine reactogenicity and immunogenicity study

The most common complaint was moderate to intense local soreness at the injection site in about $95.24 \%$ of the subjects. The local soreness persisted during all day at $90.91 \%$ of the subjects and sometimes it difused through the complete arm (45.45\%). Dizziness, fatigue and nausea were others general symptoms also related $(4.54 \%)$. These symptoms, mainly the arm soreness, tended to decrease after each sucessive vaccination (Table 3 ). It means that the vaccination did not induce clinical hypersensitivity reactions to vaccine components ${ }^{1.14}$. The described symptoms were similar to the ones observed by others authors 1.2 .7 and they were not incapacitating?

The seroconversion to anti-HBs was detected in $63.63 \%$ of the vaccinees after the first dose, in $77.24 \%$ after the second, and in $95.3 \%$ after the third dose (Table 4). The anti-HBs geometric mean titres increased progressively from $17.5 \mathrm{IU} / \mathrm{l}$ to 152.3 and to $2718 \mathrm{IU} / \mathrm{l}$ after the three successive vaccinations, respectively. The mean age of the subjects in this study were 30 years (subjects between 20 and 46 years). The only one non-responder subject was the oldest one in the group (46 years old). Besides, the subjects that had the titres between 10 and $100 \mathrm{IU} / \mathrm{I}$ corresponded to $75 \%$ of the subjects with the ages over 33 years. The subjects with the titres between 300 and 29,500 IU/l corresponded to $80 \%$ of the subjects with less than 32 years old. SEGAL ${ }^{10}$ described as a successful immunization, $94 \%$ of less than 30 years old responders and not so effective (54\%) for over 30 years responders. Seroconversion differences due to the age were described before.

TABLE 3

Percentages of observed side effects after each administration $10 \mu \mathrm{g}$ dose of Instituto Butantan's recombinant hepatitis B vaccine.

\begin{tabular}{cccc}
\hline Side effects & 1st. dose & 2nd. dose & 3rd. dose \\
\hline arm soreness & $95.24 \%$ & $40.91 \%$ & $38.10 \%$ \\
fatigue & $4.54 \%$ & $0 \%$ & $0 \%$ \\
diziness & $4.54 \%$ & $* 0 \%$ & $0 \%$ \\
nausea & $4.54 \%$ & $0 \%$ & $0 \%$ \\
\hline
\end{tabular}


COSTA, A.A.; INENAMI, M.; JUAREZ. E.; LLACEN, P.D. \& RAW, I. - Preliminary report of the use on adults of a recombinant yeast-derived hepatitis B vaccine manufactured by Instituto Butantin. Rev. Inst. Med. trop. S. Paulo, 39(1): 39-42, 1997.

TABLE 4

Anti-HBs titres and seroconversion rates (\%) for subjects injected with $10 \mu \mathrm{g}$ of recombinant vaccine at 0,1 and 6 months.

\begin{tabular}{ccccc}
\hline \multicolumn{5}{c}{ Anti-HBs (IU/I) } \\
\hline Dose & $<\mathbf{1 0}$ & $\mathbf{1 0 - 1 0 0}$ & $\mathbf{1 0 0 - 1 0 0 0}$ & $>\mathbf{1 0 0 0}$ \\
\hline Ist & $8 / 22(36.36 \%)$ & $10 / 22(45.45 \%)$ & $4 / 22(18.18 \%)$ & $0 / 22(0 \%)$ \\
2nd & $5 / 22(22.73 \%)$ & $13 / 22(59.1 \%)$ & $3 / 22(13.64 \%)$ & $1 / 22(4.54 \%)$ \\
3rd & $1 / 21(4.76 \%)$ & $10 / 21(47.62 \%)$ & $4 / 21(19.05 \%)$ & $6 / 21(28.6 \%)$ \\
\hline
\end{tabular}

Children were better responders than young adults (20 years old), 98 versus $80 \%$ respectively". Another study showed $100 \%$ of seroconversion after the third dose using another yeast-derived vaccine $(20 \mu \mathrm{g})$ and a more homogeneous and younger population (mean age between $24-26$ years old). The geometric mean titres were 13, 35 and $628 \mathrm{IU} / \mathrm{l}$ after the three successive doses². Other $10 \mu \mathrm{g}$ vaccine, in the same study, had seroconversion results very similar to the Butantan's vaccine, $(27,83,93 \%)$, but its population age was more homogeneous. The authors concluded that the vaccines were safe and effective. This conclusion can be extended to the Butantan's vaccine. Table 5 showed clinical evaluations of Hepatitis B vaccines described in the literature. The question age/seroconversion and dose can be better analysed in terms of modifications in the vaccination schedules for oldest subjects. The suggestion of a booster in the month 12 in this cases, could be usefull $1.9,12$.

\section{CONCLUSION}

The clinical trial of the recombinant hepatitis $B$ vaccine from Instituto Butantan was considered satisfactory in terms of immunogenicity (titers between 17.5-29500 IU/l, seroconversion 95.3\%) and reactogenicity (no incapacitating side effects).

TABLE 5

Clinical evaluation of some hepatitis B vaccines.

\begin{tabular}{cccc}
\hline Vaccine & Dose $(\boldsymbol{\mu g})$ & Potency $(\mathbf{I U} / \mathrm{l})$ & Reference \\
\hline $\begin{array}{c}\text { Butang- } \\
\text { (Brazil) }\end{array}$ & 10 & 2718.0 & \\
MSD & 10 & 388.6 & 6 \\
(USA) & 20 & 519.5 & \\
MSD & 10 & 1526.0 & 3 \\
(USA) & & & \\
MSD & 5 & 479.0 & 9 \\
(USA) & 20 & 228.7 & \\
SKB & 20 & 1649.0 & 4 \\
(Belgium) & & & 7 \\
SKB & 20 & 2094.0 & 5 \\
(Belgium) & & & \\
SKB & 20 & 1517.0 & \\
(Belgium) & 20 & 190.0 & \\
\hline
\end{tabular}

\section{RESUMO}

\section{Avaliação clínica da vacina recombinante contra hepatite $B$ produzida no Instituto Butantan}

Três doses de $10 \mu \mathrm{g}$ da vacina recombinante contra hepatite B, produzida pelo Instituto Butantan, através de tecnologia própria, foram administradas numa população de adultos (idade média 30 anos), seguindo o esquema de imunização 0.1 e 6 meses após a primeira dose. A avaliação clínica da vacina foi considerada satisfatória em termos de imunogenicidade (títulos dos anticorpos anti-HBs entre 17,5-29500 UI/1, soroconversão $95,3 \%$ ) c reatividade (sem efeitos colaterais e sintomas clínicos relevantes).

\section{REFERENCES}

1. ANDRÉ, FE. \& SAFARY, A. - Summary of clinical findings on Engerix-B. a genetically engineered yeast-derived hepatitis B vaccine. Postgrad. med. J., 63(suppl. 2):169-178, 1987

2. BERGAMINI, F. \& ZANETTI, A. - Immunogenicity of yeast-derived hepatitis $B$ vaccines in young adults. Postgrad. med. J., 63(suppl. 2):137-138. 1987

3. DAVIDSON, M. \& KRUGMAN. S. - Immunogenicity recombinant yeast hepattis $B$ vaccine. Lancet, 1:108-109, 1985

4. GONZALEZ. M.L.; USANDIZAGA, M.: ALOMAR, P.: SALVA. F. \& MARTIN F. - Intradermal and intramuscular route for vaccination against hepatitis $B$. Vaccine, 8:402-405, 1990 .

5. GOUdEAU, A.; DENIS, F; MOUNIER, M. et al. - Comparative multicentre study of the immunogenicity of different hepatitis $B$ vaccines in healthy volunteers Postgrad. med. J., 63:(suppl. 2):125-128, 1987.

6. HOLLINGER, F.B.; TROISI, C.L. \& PEPE. P.E. - Anti-HBs responses to vaccination with a human hepatitis B vaccine made by recombinant DNA technology in yeast. J. infect. Dis., 153:156-159, 1986.

7. JUST, M.; BERGER, R. \& JUST, V. - Reactogenicity and immunogenicity of it recombinant hepatitis $B$ vaccine compared with a plasmal-derived vaccine in young adults. Postgrad. med. J., 63(suppl. 2):121-123, 1987.

8. KUBRUSLY, F.S.; IOSHIMOTO, L.M.; MIYAKI. C. et al. - Quality control tests of a recombinant yeast-derived Hepatitis B vaccine (Unpublished datia. 1996).

9. KUWERT, E.; SCHEIERMANN, N.; GESEMANN. M. et al. - Dose range study in healthy volunteers of a hepatitis B vaccine produced in yealst. Antivir. Res., (suppl. 1):281-288, 1985.

10. SEGAL, G.R. - Hepatitis B immunization. Med. J. Aust., 154:70. 1991.

11. WAINWRIGHT, R.B.; McMAHON, B.S.; BULKOW, A.J. et al. - Duration of immunogenicity and efficacy of hepatitis B vaccine in a Yupik Eskimo population. Preliminary results of a 8-year study. In: INTERNATIONAL SYMPOSIUM OF VIRAL HEPATITIS AND LIVER DISEASE. Baltimore. 1990. Proceedings. p. $762-766$. 
COSTA, A.A.; INENAMI, M.; JUAREZ. E., LLACEN, P.D. \& RAW, I. - Preliminary report of the use on adults of a recombinant yealst-derived hepatitis B varcine manufictured by Instituto Butintin. Rev. Inst. Med. trop. S. Paulo, 39(1):39-42. 1997.

12. WEST, D.J. \& CALANDRA, G.B. - Viccine induced immunologie memory for Hepatitis $B$ surface antigen: implications for policy on booster vaccination. Vaccine, 14:1019-1026, 1996

13. WHO - Requirements for Hepatitis B vaccines made by recombinant DNA techniques. WId. HIth. Org. techn. Rep. Ser., (786), 1989.
14. WIEDERMANN, F.: AMBROSCH, P.: KREMSNER, C. et ill, - Reatogenicily and immunogenicity of different lots of a yealst-derived hepatitis $B$ valceine. Postgrad. med. J., 63 (suppl. 2):109-112. 1987.

Recebido para publicação em 12/11/1996

Aceito para publicação em 19/02/1997 